\title{
Morphodynamics of the Morfa Dyffryn coastal dunes, mid-Wales: photographic survey 1988-2007
}

\author{
J. A. Millington ${ }^{1}$, M. A. Fullen ${ }^{2}$, G. M. Moore ${ }^{2}$, C. A. Booth ${ }^{1}$, \\ I. C. Trueman ${ }^{2}$, A. T. Worsley ${ }^{3} \&$ N. Richardson ${ }^{3}$ \\ ${ }^{I}$ SEBE, University of Wolverhampton, UK \\ ${ }^{2} S A S$, University of Wolverhampton, $U K$ \\ ${ }^{3} N G A S$, Edge Hill University, UK
}

\begin{abstract}
In this 20-year case study on the Morfa Dyffryn dunes, Gwynedd, mid-Wales (National Grid Reference: SH563240), straightforward and inexpensive photography, from fixed points and angles, proved useful for monitoring the evolution and migration of dynamic dune landforms. The mobile foredunes are particularly dynamic with cyclical morphological development paralleling an overall landward recession, evident by exposure of a World War II bunker in 1995. A cyclical trend is documented through photosets. The dune meadow has undergone cyclical patterns of sand encroachment, followed by stabilization by vegetation, while the fixed hind dunes remain stable. A general relationship between foredune morphology and erosion/accretion processes has been established, offering the prospect of predicting future dune morphological changes.
\end{abstract}

Keywords: coastal dunes, photographic survey, erosion/accretion processes, pedogenic development, coastal change.

\section{Introduction}

Erosion, transport and deposition processes lie at the core of geomorphological recognition, but lack of appropriate monitoring techniques has limited progress in understanding. Geomorphologists rely on low-resolution, frequently updated, 
field monitoring, such as repeat photography, in all earth science disciplines (e.g. [1]). Routine use of photographic surveys to monitor dynamic environments is a very useful tool. For instance, this technique has been used to analyse forest changes during the past century in the San Juan Mountains of Colorado, U.S.A. [2], and widespread glacier recession has been documented using repeat photography in north-western Patagonia [3].

The extent of coastal aeolian processes, coupled with limited vegetation coverage and the high erodibility of dune sands, make coastal dunes susceptible to rapid morphological adjustments [4]. Therefore, regular and consistent monitoring is necessary to identify and record changes and trends. Repeat ground photography can show, in a simple yet powerful way, the impacts of recent coastal changes on these sensitive dune environments. Changes in foreshore level and frontal dune erosion/accretion have been recorded on some British coasts since the 1950 s by measurements relative to fixed points (e.g. the North Norfolk coast, Eastern England [5] and the Sefton coast, NW England [6]). On a larger scale, an automated video camera system has been deployed to document erosion of dunes, barrier islands and inlet channels on the Algarve coast of Portugal [7].

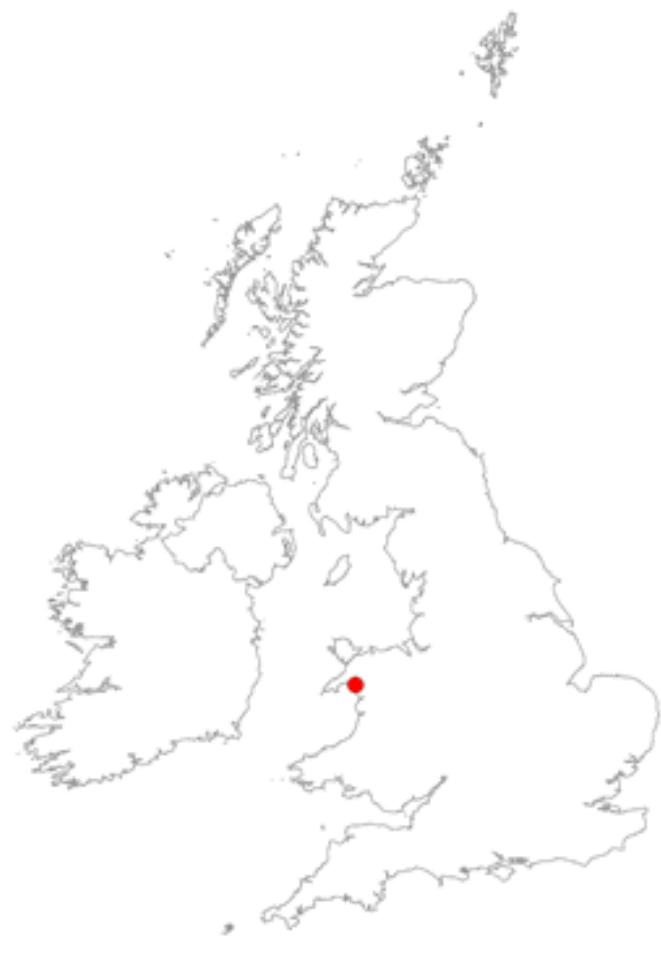

Figure 1: $\quad$ Location of Morfa Dyffryn within the British Isles. 
In this paper, dune dynamics on a section of the Morfa Dyffryn dunes, Gwynedd, mid-Wales (National Grid Reference: SH563240) (Figure 1), have been monitored. These are presented through annual photographic surveys of dune morphology, since June 1988 to the present day, and will continue as an ongoing programme of morphological monitoring. Morfa Dyffryn is a $10.6 \mathrm{~km}^{2}$ transgressive dunefield, in which the parabolic dunes lie sub-parallel to the prevailing south-westerly winds. Rates of parabolic dune migration in this area are not currently known, but are believed to be comparable to dune migration rates at Aberffraw, Anglesey, north Wales, ranging from 0-3.6 $\mathrm{m} \mathrm{year}^{-1}$, with a mean migration rate of $1 \mathrm{~m} \mathrm{year}^{-1}$ [8]. However, these migration rates are low compared with the parabolic dunefield of Newborough Warren, Anglesey, where migration rates of 1.5-6.7 $\mathrm{m}^{y^{-1}}$ over a 3-year period have been determined [9].

\section{Methods}

Three monitoring stations were selected along a transect, oblique to the shore, for Fixed-Point-Photography (FPP) analysis: (i) Station 1, upper beach (SH 56685 23087); (ii) Station 2, mobile dune peak (SH 56725 23142) and (iii) Station 3, fixed dune (SH 56828 23204). Photographs were taken from fixed angles, determined using a prismatic compass. Occasionally the view from the previous year's photo point was obscured by vegetation/dune height growth. If an alternative clearer dune-view could not be obtained within $\sim 25 \mathrm{~m}$, the photo was not used.

The expanding database now contains 23 photosets and an archive of 195 photographs. The systematic evaluation of 17 photosets was initially combined with field observations to identify trends in coastal dune change. Exposure of a Second World War bunker in 1995 facilitated the addition of a further four photosets, and a further two sets were added in 2007, following field observations of an advancing pebble ridge. Photosets predating 2006 were in slide format, which have been scanned at high resolution for digital analysis. Image-processing software (Adobe Photoshop CS2 version 9, 2005) was used to digitally match photosets by layering one photo over the other for alignment.

Within a photo comparison, morphological features were analysed for increase, decrease or stability, based on already successful methodologies [2]. An increase in extent was documented when a major dune morphological feature or vegetation type clearly occurred in new areas not occupied in the previous year's photograph. A decrease in extent was recorded when a dune morphological feature or vegetation type clearly occupied less area than in the previous year's photograph. The degree of increase or decrease was classified as either moderate or extensive. However, the distinction between moderate and extensive changes is subjective, and estimations of area change are difficult. Vertical dune growth can sometimes block the view of areas, making them appear smaller due to sand encroachment. 


\section{Results}

The mobile foredunes are particularly dynamic and migrated landwards during the first 10 years of monitoring (1988-1998). Extensive dune deflation and subsequent burial of a fence is evident in the photographic sequence shown in Figure 2. The dominant landscape feature in 1988 is clearly a dune peak. An extensive change occurred in 1990, due to a later phase of deflation, as the dune pyramidal peak was replaced by an open dune field, followed by accretion of the same dune peak again within $\sim 6$ year cycle period. Rapid colonization of marram grass, during the accretion phase beginning in 1994, has encouraged foredune height growth and subsequent stabilization. This stabilization of deflated sand supported embryo dune development seaward of the main foredune landscape, up until mid-way through the first decade of the millennia, when a decrease in the extent of these embryo dunes can be observed. However, the overall foredune status during the last decade is considered stable, as only minor subtle changes in the embryo dunes are visible. In contrast, the morphological shape and boundary locations between bare sand and dune vegetation remain unchanged since 1998 .

Further evidence of landward recession of the foredunes is provided by the appearance of a Second World War bunker in 1995. Figure 3 shows the progressive exposure of the south-facing window and subsequent sand deflation adjacent to and beneath the bunker.

The fixed hind dunes remained morphologically stable throughout the monitoring survey and any areas of bare sand were progressively colonized by marram grass (Figure 4). A large expanse of dune meadow, containing typical species such as Creeping willow (Salix repens) and Fen sallow willow (Salix cinerea), occurs behind the main foredune landscape. This area, however, underwent rapid burial following a period of sand encroachment in 1990, which subsequently became re-colonized and stabilized by marram grass by 1996 . This is considered a moderate change, as the sand apron is gradually re-colonized by dune meadow year by year. However, differences between 2001 and 2006 photographs are considered extensive, as the dune meadow appears to be completely recovered from the initial blowout event.

\section{Discussion}

Previous studies have identified that changes in beach morphology can suggest impending changes in the erosion/accretion status and morphology of frontal dunes [6]. For instance, analysis of topographic beach profile data on the Sefton coast, confirmed changes in beach morphology and provided an indicator of the onset of frontal dune erosion [10]. At Morfa Dyffryn the disappearance of the dune peak in 1990 is an indication of the re-deposition of aeolian derived sand in the hind dunes. Also, identification of upper beach embryo dune accretion, in 1994 and 2001, coincides with the redevelopment of the dune peak in the foredunes. The dune peak, in the centre of a blowout environment, appears to grow in height between 1990 and 1994, and again in 2001. This is a result of 

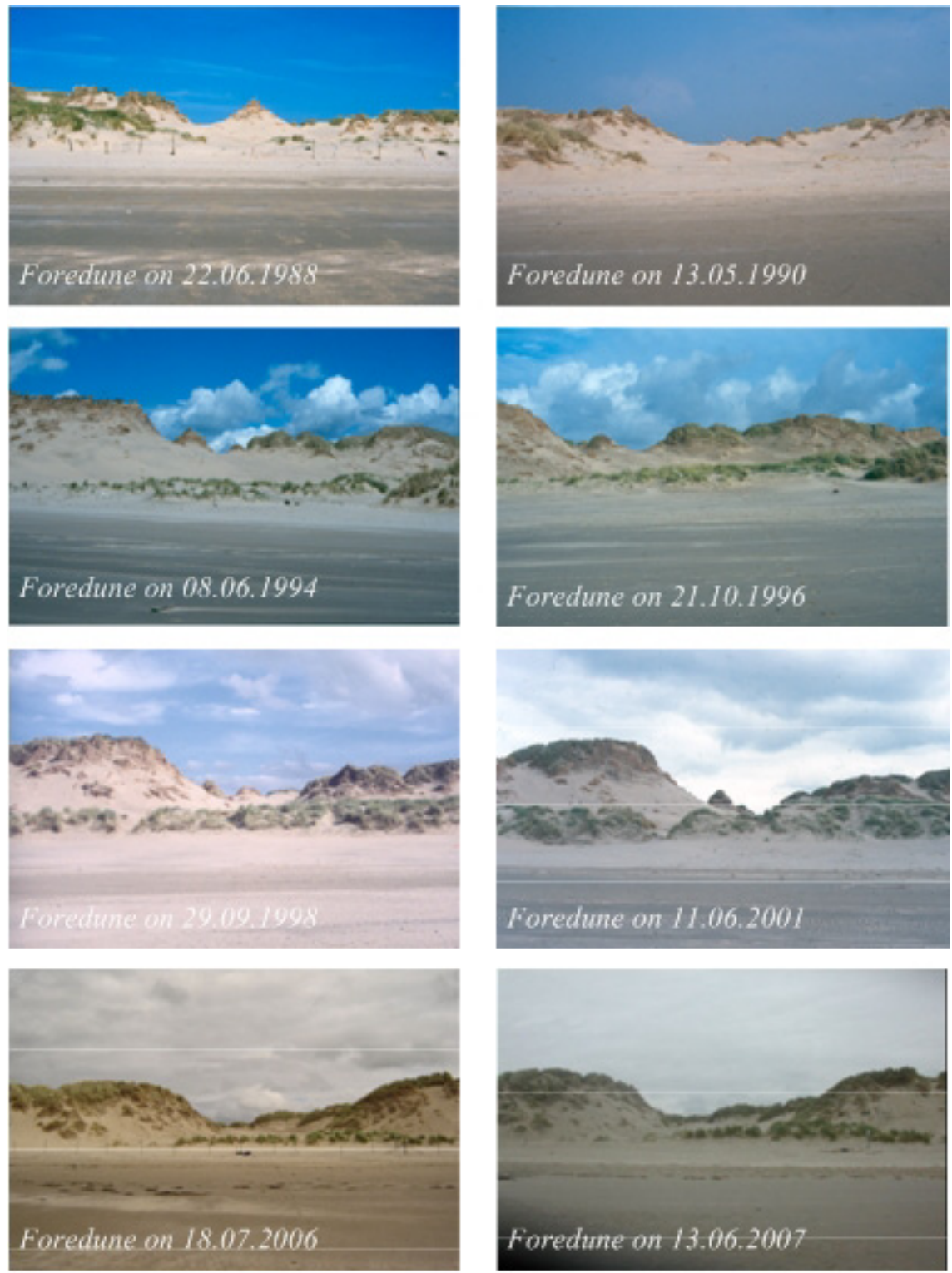

Figure 2: $\quad$ Photograph of view from beach to foredune. Note dune deflation and destruction of the fence, following by accretion and then deflation of the dune 'pyramidal peak' (Station 2). Also note development of the embryo foredune and colonization by Ammophila arenaria in 1994. This appears much less established in 2006. 

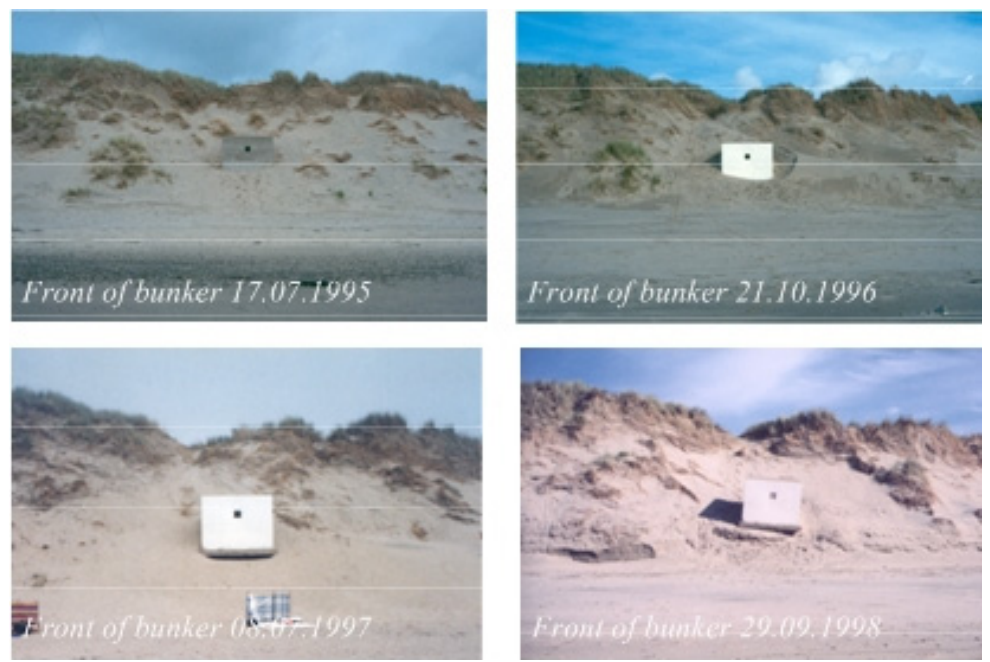

(a)
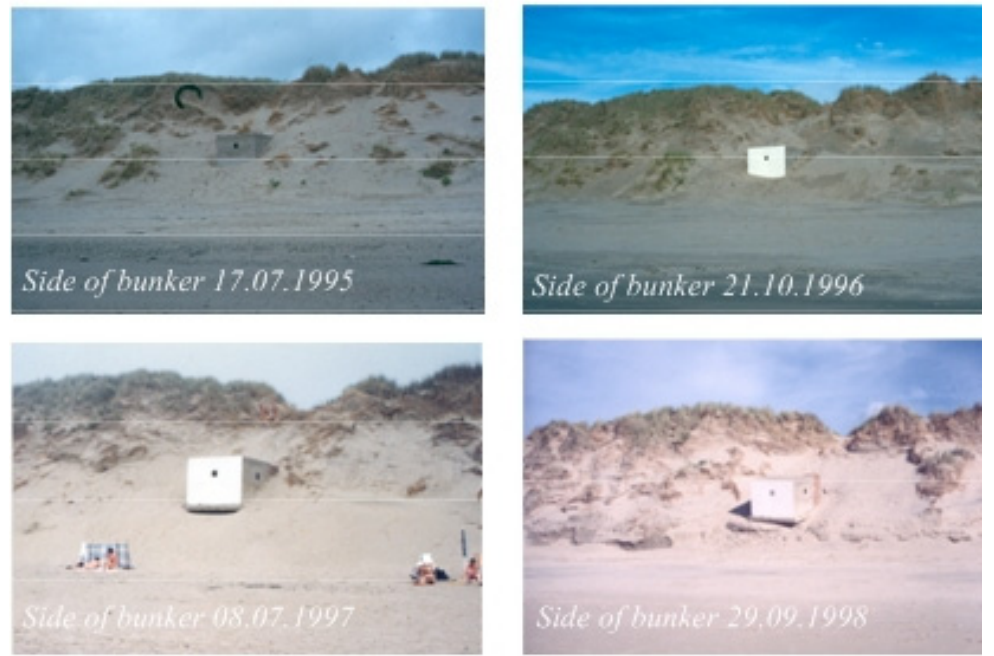

(b)

Figure 3: (a) View directly in front of the war bunker. In 1995, a Second World War bunker became visible in the foredunes and provided a new fixed point. Observe the deflation of sand. (b) View from the south side of the bunker. Observe the exposure of the south-facing and undercutting of the concrete platform.

aeolian derived sand, from a positive beach and foredune budget, moving into the gap and been trapped by vegetation. However, successive embryo dune colonization by marram grass appears to signify a change from stability to erosion in the foredunes and subsequent deflation of the dune peak in 1996, 

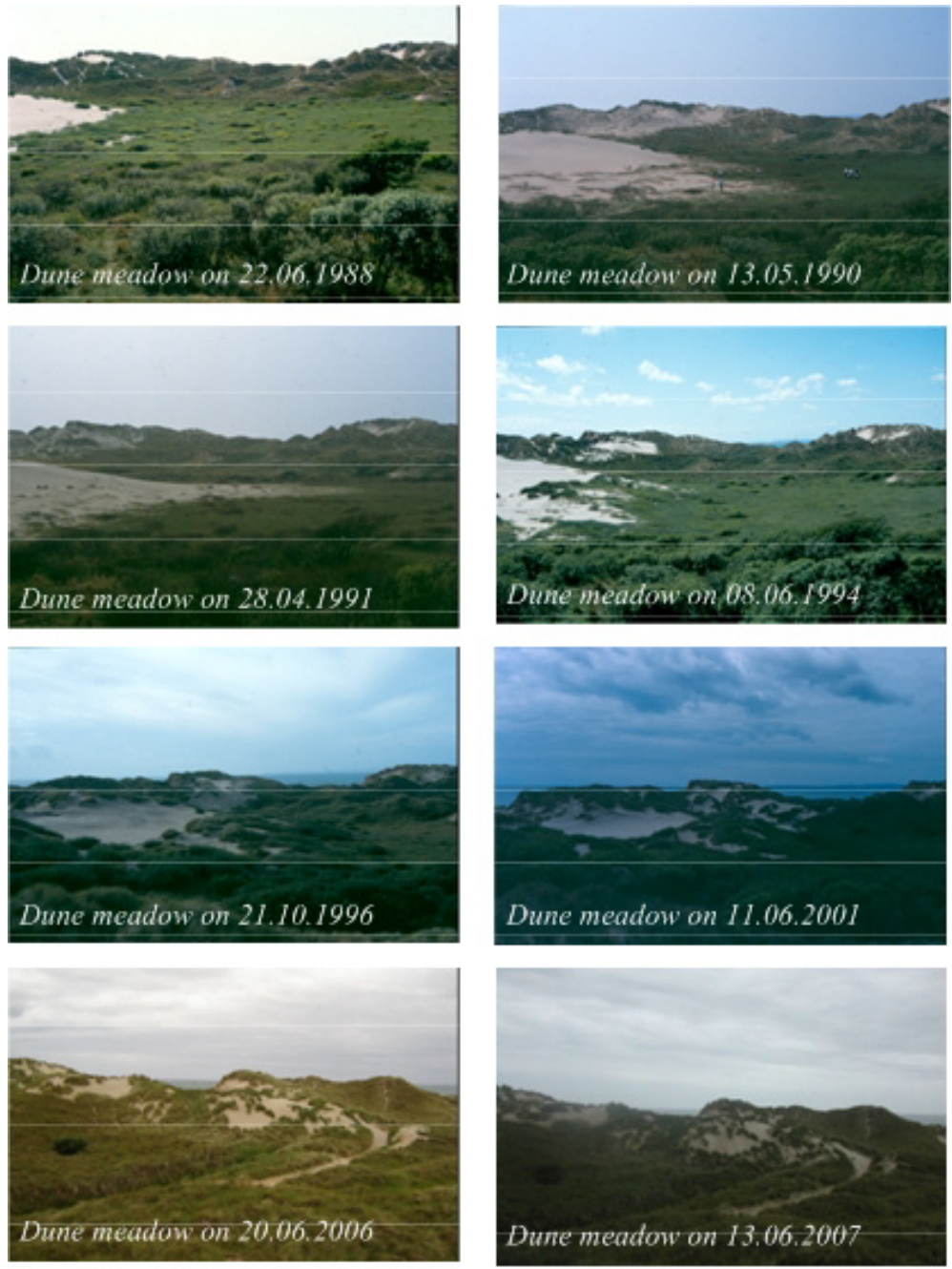

Figure 4: $\quad$ View west from Station 3. Deflated sand from the foredune was deposited on the dune slack, burying dune meadow vegetation. Vegetation then recolonized the 'sand apron'. Pedological analyses of soil profiles beneath the willow (salix cinerea) copse suggest cyclical patterns of the dune deflation and stabilization. Note that otherwise the hind dune remained morphologically stable.

possibly as a result of a negative upper beach sediment budget, due to limited availability of loose sand. Sand deflation at this time is also evident by the exposure of the war bunker in 1995. A conceptual model based on sediment budget has been proposed [11], which relates dune morphology to shoreline dynamics and dune forming factors. Therefore, two sediment budget situations, 
taken from four possible situations in this existing model, are evident for this part of the coast:

i. Negative beach and foredune budget, associated with washover, or foredune attenuation (featuring blowouts, parabolic re-entrants or hummocks).

ii. Negative beach budget, positive foredune budget, associated with foredune development, with maximum foredune height occurring where the beach is slightly erosional.

It is likely the dune peak formation is associated with stabilization and vegetation colonization; however, it is a 'chicken-and-egg' problem whether the subsequent deflation of the peak is a result of embryo dune building and, therefore, a lack of sediment in the foredunes, or whether it is the onset of erosion creating embryo dunes out of sediment derived from the dune peak. A similar problem was encountered on the Danish North coast where it could not be determined whether steepening of a shoreface was a result of onshore bar migration and landward sediment transfers, or whether onshore bar migration had been caused by an increasing shoreface slope [12]. Since migration processes acting on dynamic dune systems are determined by wind direction relative to dune alignment [13], it would seem more likely that deflation and accretion of the dune peak is the outcome of at least two, asymmetric, erosive wind directions, one of which is more dominant and effective, creating a slip face on the lee side of the peak.

For such parabolic dunes, migration of the dune peak, which is readily identifiable in the photographs, could be used to measure overall migration rates of the entire mobile dune system. However, it is possible for the morphology to change so as it is no longer possible to identify the same morphological feature between several photographs. Overall, these comparisons reveal that over the past two decades the environmental conditions in the region have clearly favoured accumulation over deflation in the mass balance of these dunes.

Initial analyses of soil profiles beneath the dune pasture suggest cyclical morphological development, alternating between phases of deflation and stabilization [14]. $\mathrm{Cu}$ horizons (weathered parent material) are indicative of periods of dune instability and domination by aeolian processes, which subsequently become modified to Ah horizons (mixed mineral and organic matter) during periods of re-vegetation and stability [15].

\section{Conclusions}

Repeated photography comparisons of sand dune dynamics provide baseline information about the long-term behaviour of local dune systems. Evidence has documented two decades of coastal dune change that displays remarkable stability in the hind dunes, extensive invasions of meadow vegetation on the fixed dunes, cycles of sand encroachments on the mobile dunes, substantial growth and subsequent deflation of the foredunes, and considerable capacity for recovery, even after severe disturbances. The cost effective and time efficient survey illustrates a general cyclical relationship between upper beach dynamics, 
dune morphology, and erosion/accretion processes, which can inform the process of shoreline management. When coupled with existing beach monitoring [10], this survey technique could advance understanding of beach-dune dynamics and sedimentary budgets.

\section{References}

[1] Harvey, A.M., Event frequency in sediment production and channel change. River Channel Changes, ed. K.J. Gregory, Wiley: Chichester, pp. 301-315, 1977.

[2] Zier, J.L. \& Baker, W.L., A century of vegetation change in the San Juan Mountains, Colorado: An analysis using repeat photography. Forest Ecology and Management, 228, pp. 251-262, 2006.

[3] Masiokas, M.H., Villalba, R., Luckman, B.H., Lascano, M.E., Delgado, S. \& Stepanek, P., $20^{\text {th }}$-century glacier recession and regional hydroclimatic changes in northwest Patagonia. Global and Planetary Change, In Press, 2007.

[4] Anderson, J.L. and Walker, I.J., Airflow and sand transport variations within a backshore-parabolic dune plain complex: NE Graham Island, British Columbia, Canada. Geomorphology, 77, pp. 17-34, 2006.

[5] Livingstone, D., Raper, J. \& McCarthy, T., Integrating aerial videography and digital photography with terrain modelling: an application for coastal geomorphology. Geomorphology, 29, pp. 77-92, 1999.

[6] Saye, S.E., van der Wal, D., Pye, K. \& Blott, S.J., Beach-dune morphological relationships and erosion/accretion: An investigation at five sites in England and Wales using LIDAR data. Geomorphology, 72, pp. $128-1552005$.

[7] Morris, B.D., Davidson, M.A., Huntley, D.A., Measurements of the response of a coastal inlet using video monitoring techniques. Marine Geology, 175, pp. 251-272, 2001.

[8] Bailey, S.D. \& Bristow, C.S., Migration of parabolic dunes at Aberffraw, Anglesey, north Wales. Geomorphology, 59, pp. 165-174, 2004.

[9] Ranwell, D., Movement of vegetated sand dunes at Newborough Warren, Anglesey. Journal of Ecology, 46, pp. 83-100, 1958.

[10] Pye, K. \& Neal, A., Coastal dune erosion at Formby Point, north Merseyside, England: causes and mechanisms. Marine Geology, 119(1-2), pp. 39-56, 1994.

[11] Psuty, N.P., Spatial variation in coastal foredune development. Coastal Dunes; Geomorphology, Ecology and Management for Conservation, ed. R.W.G. Carter, T.G.F. Curtis \& M.J. Sheehy-Skeffington, Proceedings of the Third European Dune Congress, Galway, Ireland, 17-21 June 1992. A.A. Balkema, Rotterdam, 1992.

[12] Aagaard, T., Davidson-Arnott, R., Greenwood, B., Nielsen, J., Sediment supply from shoreface to dunes: linking sediment transport measures and long-term morphological evolution. Geomorphology, 60, pp. 205-224, 2004. 
[13] Tsoar, H., Blumberg, D.G. \& Stoler, Y., Elongation and migration of sand dunes. Geomorphology, 57, pp. 293-302, 2004.

[14] Fullen, M.A. \& Moore, G., Photographing dune dynamics. Geography Review, November, pp. 14-17, 1999.

[15] Leatherman, S.P., Barrier dune systems: A reassessment. Sediment Geology, 24(1-2), pp. 1-16, 1979. 